\title{
Are children undergoing cardiac surgery receiving antibiotics at subtherapeutic levels?
}

\author{
Jennifer H. Huang, MD, ${ }^{a}$ Rachel Sunstrom, PA, ${ }^{b}$ Myrna Y. Munar, PharmD, ${ }^{c}$ Ganesh Cherala, PhD, ${ }^{c}$ \\ Arthur Legg, MD, ${ }^{a}$ Ali J. Olyeai, PharmD, ${ }^{c}$ and Stephen M. Langley, MD, FRCS (CTh) ${ }^{b}$
}

\begin{abstract}
Objectives: Perioperative antibiotics have decreased—but not eradicated—postoperative infections. In patients undergoing cardiac surgery with cardiopulmonary bypass, the dilutional effect of the priming and any additional volume given during the procedure may lead to subtherapeutic antibiotic levels. Our aim was to determine if children undergoing cardiac surgery with cardiopulmonary bypass receive perioperative antibiotics at subtherapeutic levels.
\end{abstract}

Methods: Using published pharmacokinetic data on cefuroxime, we developed a computer simulation model to generate a nomogram predicting patients at risk for subtherapeutic cefuroxime levels based on time from initial dosing and additional volume given.

Results: A computer-generated 1-compartment pharmacokinetic model was created to predict cefuroxime plasma levels over time for patients of all weights and additional volumes given for both a $25-$ and $50-\mathrm{mg} / \mathrm{kg}$ intravenous dose. For example, following a $25-\mathrm{mg} / \mathrm{kg}$ dose, a patient receiving an additional volume of 275 $\mathrm{mL} / \mathrm{kg}$ is predicted to be subtherapeutic $(<16 \mathrm{mg} / \mathrm{L}=4 \times$ minimum inhibitory concentration) at 4 hours. Our nomogram predicts all patients will be subtherapeutic at 8 hours, consistent with general pediatrics dosing schemes. Following a 50-mg $/ \mathrm{kg}$ dose, levels are predicted to be subtherapeutic after an additional volume of 315 $\mathrm{mL} / \mathrm{kg}$ at 5.5 hours.

Conclusions: Our model predicts which patients undergoing cardiac surgery with cardiopulmonary will have subtherapeutic cefuroxime levels. This nomogram enables providers to determine when to administer additional antibiotics in patients receiving large additional volumes during cardiac surgeries. This rational approach to perioperative antibiotic dosing may result in a reduction in postoperative infection in this vulnerable patient population. (J Thorac Cardiovasc Surg 2014;148:1591-6)

Postoperative wound infections in pediatric patients undergoing cardiothoracic surgery occurs in $2.3 \%$ to $8 \%$ of patients. ${ }^{1}$ This complication results in increased morbidity, longer hospitalizations, and increased cost-with more than $\$ 1.6$ billion annually in extra hospital charges reported. ${ }^{2}$ In particular, the financial burden is becoming a more urgent concern for our field as insurance reforms limiting the reimbursement for these preventable complications become more common. Within the United States in 2007, Medicare began refusing reimbursement for postoperative mediastinitis in patients who have undergone coronary artery bypass grafting. ${ }^{3}$ One major strategy in

\footnotetext{
From the Divisions of Pediatric Cardiology ${ }^{\mathrm{a}}$ and Pediatric Cardiac Surgery, ${ }^{\mathrm{b}}$ Doernbecher Children's Hospital, Oregon Health Science University, Portland, Ore; and College of Pharmacy, ${ }^{\mathrm{c}}$ Oregon State University, Corvallis, Ore.

J.H.H. is supported by a National Institutes of Health T32 grant.

Disclosures: Arthur Legg reports consulting fees from and equity ownership in Waxit Histology Services. Stephen M. Langley reports lecture fees from Cormatirx. All other authors have nothing to disclose with regard to commercial support.

Received for publication June 25, 2013; revisions received Dec 4, 2013; accepted for publication Dec 24, 2013; available ahead of print Feb 9, 2014.

Address for reprints: Jennifer H. Huang, MD, 707 SW Gaines St, Center of Development and Rehabilitation-Pediatrics, Portland, OR 97239 (E-mail: huangje@ohsu. edu).

$0022-5223 / \$ 36.00$

Copyright (c) 2014 by The American Association for Thoracic Surgery

http://dx.doi.org/10.1016/j.jtcvs.2013.12.043
}

limiting postoperative surgical site infections has been the use of perioperative antibiotics to reduce primarily grampositive skin flora that colonizes the skin and can potentially infect an open wound. ${ }^{4-7}$ Since the days of Lister's introduction of carbolic acid spray in the 1860 s and Burke's demonstration of the efficacy of perioperative antibiotics in guinea pigs in the $1960 \mathrm{~s},{ }^{8}$ postoperative wound infections have decreased dramatically. This strategy is used across surgical subspecialties and the dosage is the same for patients regardless of the employment of cardiopulmonary bypass (CPB).

$\mathrm{CPB}$ machines require priming with a certain volume that is determined by the length and diameter of tubing, size of reservoir, and specific oxygenator. The priming volume consists of variety of different fluids that varies between institutions, including but not limited to electrolyte solutions, albumin, sodium bicarbonate, and blood. For smaller patients, the priming volume may exceed their total circulating volume. In a neonate or small infant with a circulating volume of approximately $270 \mathrm{~mL}$, the bypass priming volume could easily exceed $300 \mathrm{~mL}$ using various commonly used oxygenators and cardioplegia setups.

We know that the antibiotic levels can be subtherapeutic in a percentage of adult patients undergoing cardiac surgery using $\mathrm{CPB} .{ }^{6,7}$ Although a previous small study in pediatric 


$$
\begin{aligned}
& \text { Abbreviations and Acronyms } \\
& \% \mathrm{fT}=\text { percent of dosing interval } \\
& \mathrm{C}_{\max }=\text { maximum total plasma concentration } \\
& \mathrm{CPB}=\text { cardiopulmonary bypass } \\
& \mathrm{IV}=\text { intravenous } \\
& \mathrm{MIC}=\text { minimal inhibitory concentration } \\
& \mathrm{PK}=\text { pharmacokinetics } \\
& \mathrm{V}_{\mathrm{D}}=\text { volume of distribution }
\end{aligned}
$$

patients showed average cefuroxime concentrations to be therapeutic after $\mathrm{CPB},{ }^{8}$ it is unknown what percentage of individual patients were subtherapeutic. In addition, it is unknown if a difference in ages and weights was demonstrated because the sample size was perhaps too small to demonstrate a significant difference. Antibiotic levels may vary with age and weight given the variation in proportion of priming volume to circulating volume in patients of different sizes. Given this risk, some investigators have advocated the administration of an additional dose of antibiotics with the priming volume. ${ }^{9,10}$ Although cefuroxime, in particular, is a safe medication with minimal risk associated with supratherapeutic levels, further evidence is needed to justify adoption of a widespread change in published guidelines.

This risk of subtherapeutic antibiotic levels is not limited to cardiac surgery and, in fact, may be broadly applied to many other surgical fields such as trauma, orthopedics, and any surgeries requiring administration of large volumes of fluid, particularly in the pediatric population. Our aim was to determine the volume of additional fluid administration that would put a surgical patient at risk for subtherapeutic antibiotic levels and, thereby, postoperative wound infection.

\section{MATERIALS AND METHODS \\ Data Sources and Selection}

We performed a systematic search using PubMed (1970-March 2013) using combinations of the following search terms: pediatric, children, infant, neonate, cefuroxime, $C P B$, and pharmacokinetics. We then searched reference lists for additional relevant articles. In a meta-analysis of studies describing cefuroxime pharmacokinetics (PK) and pharmacodynamics in pediatric patients, 8 articles were reviewed to identify PK parameters ${ }^{9-16}$ and the mean or median of reported values are listed in Table 1. Although a 2-compartment model would give a more accurate representation of cefuroxime plasma concentration-time curves, reliable and reproducible PK parameters for a 2-compartment model have not been published. One study reported 2-compartment parameters that were not consistent with individual parameters published in the other reports. ${ }^{10}$

\section{PK Simulations}

A computer model was designed using a median or mean of PK data obtained in the studies found above. Nascimento and colleageus ${ }^{14}$ reported a volume of distribution $\left(\mathrm{V}_{\mathrm{D}}\right)$ of $0.19,0.25$, and $0.22 \mathrm{~L} / \mathrm{kg}$ (mean, $0.22 \mathrm{~L} / \mathrm{kg}$ ), which matched the $\mathrm{V}_{\mathrm{D}}$ of $0.21 \mathrm{~L} / \mathrm{kg}$ (range, $0.081-0.423 \mathrm{~L} / \mathrm{kg}$ ) reported by Knoderer and colleagues. ${ }^{12}$ Powell and colleagues ${ }^{17}$ reported a half-life of $1.9,1.4$, and 1.9 hours (mean, 1.75 hours), which was similar to the half-life of 1.8 hours reported by del Rio and colleagues. ${ }^{16}$ Therefore, a 1-compartment PK model with first-order elimination was used. An elimination coefficient of $0.693 / 1.75$ hours or $0.396 /$ hour was used for in silico plasma concentration-time simulations following intravenous (IV) cefuroxime $25 \mathrm{mg} / \mathrm{kg}$ and $50 \mathrm{mg} / \mathrm{kg}$ doses. The $\mathrm{V}_{\mathrm{D}}$ range of 0.081 to $0.423 \mathrm{~L} /$ $\mathrm{kg}$ reported by Knoderer and colleagues ${ }^{12}$ was used to simulate priming volumes, where 0.08 represented a priming volume of $0 \mathrm{~mL} / \mathrm{kg}$ and the upper range of $0.43 \mathrm{~L} / \mathrm{kg}$ represented a priming volume of $350 \mathrm{~mL} / \mathrm{kg}(0.43$ $0.08 \mathrm{~L} / \mathrm{kg}=0.35 \mathrm{~L} / \mathrm{kg}$ or $350 \mathrm{~mL} / \mathrm{kg}$ ). Simulations were run using Phoenix WinNonLin 6.2.1.51 (Sunnyvale, Calif).

\section{Pharmacodynamic Simulations}

A minimum inhibitory concentration (MIC) for cefuroxime of $4 \mathrm{mg} / \mathrm{L}$ was used. ${ }^{14}$ According to standard clinical antibiotic dosing goals, a minimum total (bound and free drug) cefuroxime concentration of 4 times the MIC $(4 \times 4$ $\mathrm{mg} / \mathrm{L}=16 \mathrm{mg} / \mathrm{L}$ ) was chosen as a target concentration for drug efficacy. ${ }^{14,15}$ The maximum total plasma concentration $\left(\mathrm{C}_{\max }\right)$ was multiplied by the fraction unbound in the plasma $(0.5)$ to determine unbound drug concentration $\left(\mathrm{C}_{\max }\right.$, free $)$. Free drug concentrations were used to determine the time that free drug concentrations (percent of dosing interval $[\% \mathrm{fT}]$ ) were above the MIC of $4 \mathrm{mg} / \mathrm{L}$ during a dosing interval of 8 hours $(\% \mathrm{fT}>$ $\mathrm{MIC}=\left[\ln \left(\mathrm{C}_{\max }\right.\right.$, free $\left.\left./ \mathrm{MIC}\right)\right] /$ partition coefficient of cefuroxime $\left.\times 100\right) . \mathrm{A}$ $\%$ fT $>$ MIC of $50 \%$ for cefuroxime, which reflects 4 hours for an 8-hour dosing interval, was chosen for bactericidal effect. ${ }^{18}$

\section{RESULTS}

Table 2 and Figure 1 show the additional volumes at which concentrations fall below $16 \mathrm{mg} / \mathrm{L}$ (which equals the target of $4 \times$ MIC for cefuroxime) for cefuroxime at $25 \mathrm{mg} / \mathrm{kg}$ and 50 $\mathrm{mg} / \mathrm{kg}$ IV doses. The therapeutic target of $4 \times$ MIC is the widely accepted goal in antibiotics dosing schemes. After a cefuroxime $25 \mathrm{mg} / \mathrm{kg}$ IV dose, total cefuroxime plasma concentrations at 0.5 hours $\left(\mathrm{C}_{\max }\right)$ and at 2 hours remain therapeutic $(>16 \mathrm{mg} / \mathrm{L})$ for an additional volume of up to 250 $\mathrm{mL} / \mathrm{kg}$. The threshold for additional volume resulting in subtherapeutic concentrations decreases as the time from cefuroxime administration increases. Thus at 8 hours-consistent with the established dosing scheme of 8-hour dosing intervals - any additional volume would result in subtherapeutic concentrations. For example, following a $25-\mathrm{mg} / \mathrm{kg}$ dose, a patient receiving an additional volume of $275 \mathrm{~mL} / \mathrm{kg}$ is predicted to be subtherapeutic at 4 hours. Our algorithm predicts all patients will be subtherapeutic at 8 hours, consistent with general pediatrics dosing schemes.

As expected, cefuroxime plasma levels were higher for the $50-\mathrm{mg} / \mathrm{kg}$ dose of cefuroxime. Total cefuroxime plasma concentrations are therapeutic up to 5.5 hours with the administration of up to $325 \mathrm{~mL} / \mathrm{kg}$ of volume. Before dosing again at 8 hours, as little as $75 \mathrm{~mL} / \mathrm{kg}$ of volume administered would result in subtherapeutic levels. For example, following a $50-\mathrm{mg} / \mathrm{kg}$ dose, levels are predicted to be subtherapeutic after an additional volume of 255 $\mathrm{mL} / \mathrm{kg}$ at 6 hours after cefuroxime administration.

A secondary therapeutic goal in clinical antibiotic dosing schemes is unbound or free drug concentrations above the MIC for $50 \%$ of the dosing interval (which is 8 hours for cefuroxime). For cefuroxime $25 \mathrm{mg} / \mathrm{kg} \mathrm{IV}$, the time that free drug concentrations are above an MIC of $4 \mathrm{mg} / \mathrm{L}$ range 
TABLE 1. Published demographics and cefuroxime pharmacokinetic parameters in selected articles

\begin{tabular}{lcc}
\hline \multicolumn{1}{c}{ Demographic or parameter } & $\begin{array}{c}\text { Mean or median } \pm \text { standard deviation } \\
\text { (range) reported in the Results section }\end{array}$ & $\begin{array}{c}\text { Mean or median } \pm \text { standard deviation } \\
\text { (range) reported in the Abstract }\end{array}$ \\
\hline Age $(\mathrm{mo})$ & $14.2 \pm 8.65(3-33.6)$ \\
Weight $(\mathrm{kg})$ & $9.36 \pm 2.83(4.5-15.4)$ \\
Distribution clearance & $43.9 \pm 40.2 \mathrm{~mL} / \mathrm{min} / \mathrm{kg}$ & $0.050(0.041-0.058) \mathrm{L} / \mathrm{h} / \mathrm{kg}$ \\
Systemic clearance & $11.8 \pm 4.79 \mathrm{~mL} / \mathrm{min} / \mathrm{kg}$ & $0.081(0.046-0.162) \mathrm{L} / \mathrm{kg}$ \\
& Or $0.708 \pm 0.287 \mathrm{~L} / \mathrm{h} / \mathrm{kg}$ & $0.213(0.0181-0.423) \mathrm{L} / \mathrm{kg}$ \\
Volume of distribution in the peripheral compartment & $8.08 \pm 4.49 \mathrm{~L} / \mathrm{kg}$ & $3.76(1.03-6.81)^{*}$ \\
Volume of distribution in the central compartment & $8.53 \pm 3.72 \mathrm{~L} / \mathrm{kg}$ & \\
Volume of distribution at steady state & $0.2104 \pm 0.0605 \mathrm{~L} / \mathrm{kg}$ & $1.91 \pm 3.51$ \\
Half-life (h) & $0.037 \pm 0.0061 / \mathrm{h}$ & $328 \pm 102 \mathrm{mg} / \mathrm{L}$ \\
Beta & & \\
Maximum concentration & &
\end{tabular}

*Reference 12 .

from $100 \%$ to $60 \%$ of an 8 -hour dosing interval (or 8 to 4.8 hours) for priming volumes ranging from 0 to $350 \mathrm{~mL} /$ $\mathrm{kg}$. For cefuroxime $50 \mathrm{mg} / \mathrm{kg} \mathrm{IV}$, the time that free drug concentrations are above an MIC of $4 \mathrm{mg} / \mathrm{L}$ range from $100 \%$ to $80 \%$ of an 8 -hour dosing interval (or 8 to 6.5 hours) for priming volumes ranging from 0 to $350 \mathrm{~mL} / \mathrm{kg}$.

\section{DISCUSSION}

Along with cefazolin, which follows similar PK, cefuroxime is 1 of the most commonly used antibiotics in perioperative antibiotic prophylaxis across surgical subspecialties ${ }^{4}$ and is 1 of the first-line agents for antibiotic prophylaxis recommended by the Society of Thoracic Surgeons. ${ }^{5}$ However, despite its long history of use, its efficacy may be insufficient in the setting of dilution from large volumes used in certain surgical fields. Particularly in pediatrics, intraoperative volumes, including priming volume in CPB surgeries, blood products, drugs, and other fluids may have an even more deleterious dilution effect on perioperative antibiotic levels. In our model we focused on cefuroxime, although it can also be applied to cefazolin given the similar PK, including comparable half-lives $(1.68 \pm 0.55$ hours for cefazolin vs 1.75 hours

TABLE 2. Minimum additional volumes resulting in cefuroxime concentrations $\leq 16 \mathrm{mg} / \mathrm{L}$ at given times after administration

\begin{tabular}{|c|c|c|}
\hline $\begin{array}{c}\text { Time after } \\
\text { administration }(h)\end{array}$ & $\begin{array}{c}\text { Additional volume } \\
\text { (mL/kg) following } \\
25 \mathrm{mg} / \mathrm{kg} \mathrm{IV} \\
\text { cefuroxime dose }\end{array}$ & $\begin{array}{c}\text { Additional volume } \\
\text { (mL/kg) following } \\
50 \mathrm{mg} / \mathrm{kg} \text { IV cefuroxime } \\
\text { dose } \\
\end{array}$ \\
\hline 4 & $\geq 275$ & - \\
\hline 4.5 & $\geq 225$ & - \\
\hline 5 & $\geq 170$ & - \\
\hline 5.5 & $\geq 125$ & $\geq 325$ \\
\hline 6 & $\geq 90$ & $\geq 255$ \\
\hline 6.5 & $\geq 60$ & $\geq 195$ \\
\hline 7 & $\geq 35$ & $\geq 145$ \\
\hline 7.5 & $\geq 15$ & $\geq 105$ \\
\hline 8 & 0 & $\geq 75$ \\
\hline
\end{tabular}

$I V$, Intravenous for cefuroxime). ${ }^{19}$ Using our computer-generated model, we created a nomogram that enables determination of what additional volume and at what time postdose patients are at risk for subtherapeutic cefuroxime levels during CPB procedures. One clinical measure of antibiotic efficacy-the percent of dosing interval that plasma levels are above the MIC — is sufficient. However, the plasma concentration falls below the goal of 4 times the MIC for a wide range of commonly administered volumes given during the recommended 8-hour dosing interval. Subtherapeutic levels were predicted for both $25 \mathrm{mg} /$ $\mathrm{kg}$ and $50 \mathrm{mg} / \mathrm{kg}$ doses currently recommended by the Society of Thoracic Surgeons. ${ }^{4}$ It is clear with this nomogram that many patients, especially smaller patients undergoing longer bypass procedures, are at high risk for subtherapeutic perioperative antibiotic prophylaxis and may also be at high risk for postoperative infection.

Our finding is particularly interesting because the incidence of sternal wound infections has been shown to be greater in neonates compared with older children $(5.5 \%$ vs $0.5 \%){ }^{20}$ Although this incidence has decreased significantly since the introduction of perioperative antibiotics, there has not been a dramatic reduction in postoperative infection rates in recent years, which should prompt reevaluation by our subspecialty. Unfortunately, this preventable complication is a major contributor to morbidity, mortality, longer hospital stays, increased costs, and scrutiny of congenital cardiac surgery programs in today's closely monitored medical environment.

Beyond cardiac surgery, our findings can be generalized to other surgical fields, including orthopedics and trauma involving massive blood loss and in which large volumes of blood product and fluids are administered. In orthopedics in particular, postoperative infections can be devastating, especially in the setting of implanted devices. In fact, in any pediatric surgery, there is increased risk of dilution effects resulting in subtherapeutic antibiotic levels given the relatively small circulating volume in children.

There are limitations to our computer-simulated approach that uses published PK parameters for general 

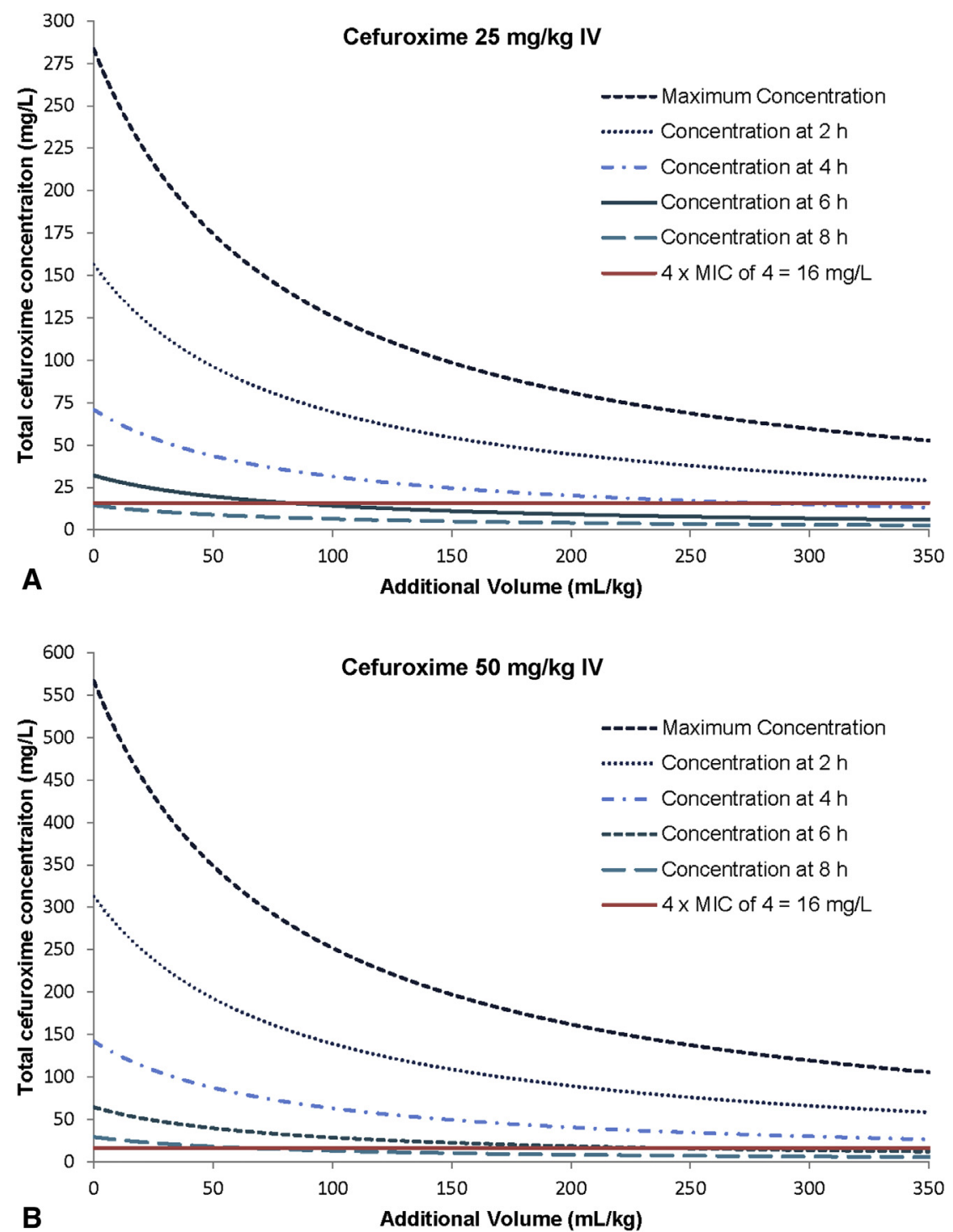

FIGURE 1. A, Simulated plasma decay curves for concentration of cefuroxime after $25 \mathrm{mg} / \mathrm{kg}$ dose given intravenously (IV) with different additional volumes administered. Each curve shows concentration at different hours after administration. The solid line indicates the goal plasma concentration of 4 times the mean inhibitory concentration $(M I C)$ and the points at which the dotted lines intersect the solid line represent the additional volumes that would result in subtherapeutic levels at given times after administration. B, Matching simulated plasma decay curves for concentration of cefuroxime after $50 \mathrm{mg} / \mathrm{kg}$ dose.

pediatric patients. Despite being a widely used antibiotic with 2-compartment PK, there is not sufficient published data for cefuroxime to create a 2-compartment model simulation. However, although using a 2-compartment model would improve accuracy in the initial immediate distribution in tissues after administration, it has little effect on predicting the later concentrations more likely to be subtherapeutic and on which we focus in our study. In fact, using a 1-compartment model may overestimate the additional volume and thereby underestimate the risk for a child to have subtherapeutic cefuroxime levels, because the initial distribution to organs such as the kidneys accelerates drug clearance before equilibrium, ${ }^{21}$ resulting in lower connective tissue levels that we target for prevention of wound infection.

Other factors unique to our patient population undergoing CPB are multiple and include altered protein-binding; loss of blood containing antibiotics; and potentially decreased drug metabolism with cooling, hypotension, hemodilution, and peribypass renal injury. At least in adults, we know that $\mathrm{CPB}$ alters cefuroxime hemodynamics. ${ }^{22,23}$ The altered protein-binding and/or the decreased metabolism may explain the long cefuroxime half-life reported by Knoderer and colleagues ${ }^{12}$ that is nearly twice the half-life reported in all other pediatric studies. The addition of protein-rich volume such as the priming volume and blood 

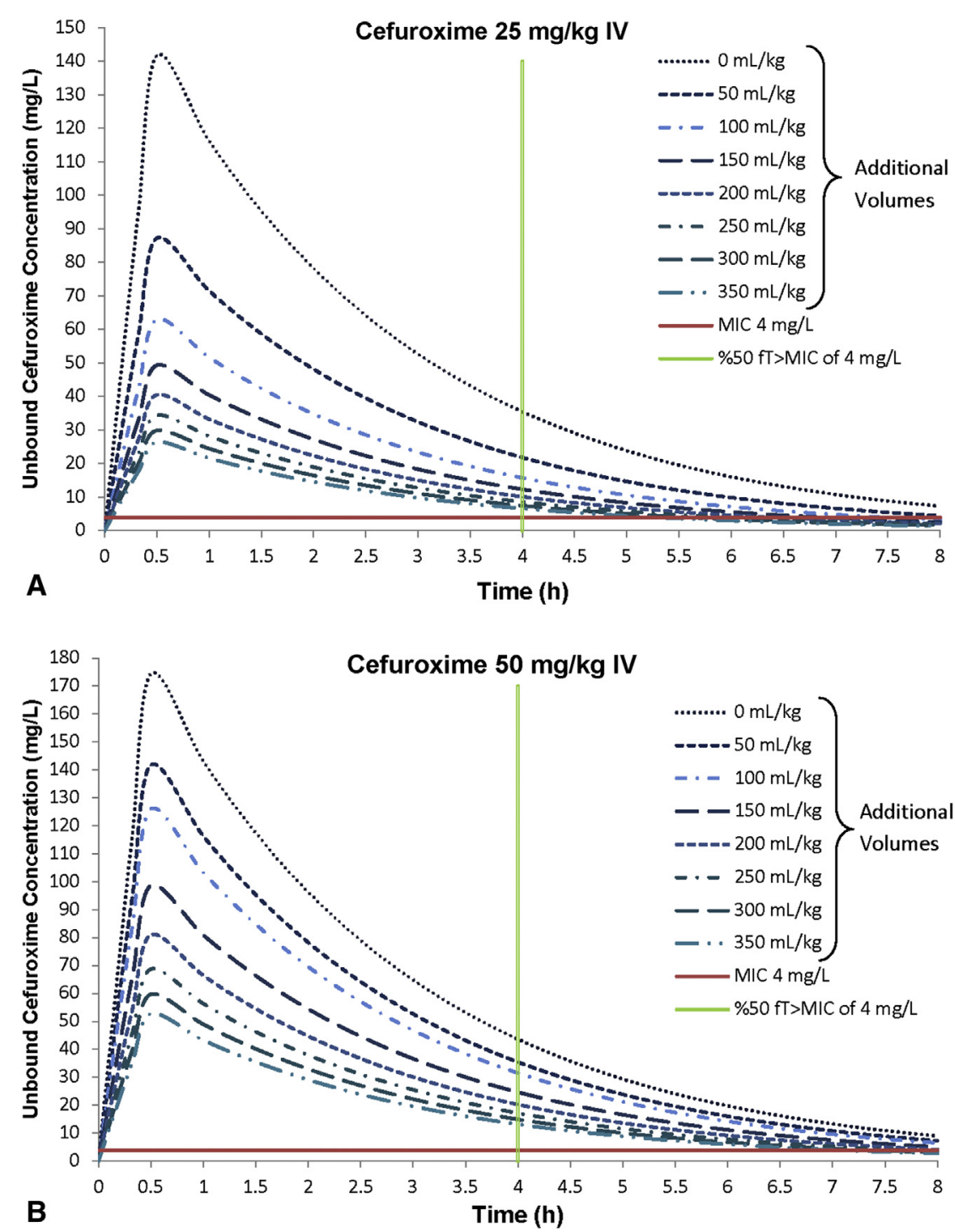

FIGURE 2. A, Simulated decay curves for unbound cefuroxime concentration after $25 \mathrm{mg} / \mathrm{kg}$ dose given intravenously (IV). The dotted lines represent concentrations after different additional volumes administered. The horizontal solid line depicts the mean inhibitory concentration (MIC) of $4 \mathrm{mg} / \mathrm{mL}$ and the vertical solid line depicts the goal time of 4 hours (50\% of the dosing interval of 8 hours) that unbound concentrations are above the MIC. B, Matching simulated decay curves for unbound cefuroxime concentration after $50 \mathrm{mg} / \mathrm{kg}$ dose. \% $\mathrm{f} T$, Time of free drug concentrations.

products, increase the substrate for protein-binding and thereby lower the free fraction concentration and tissue level of cefuroxime-which is ultimately the most accurate reflection of the level of protection from postoperative infection. This is particularly relevant because previous studies measuring only plasma levels may have overestimated tissue levels in patients undergoing CPB. ${ }^{24}$ Therefore, further studies that include free fraction and tissue levels performed in pediatric patients undergoing cardiac surgeries with CPB are necessary to validate our computer-generated model and to determine if our current perioperative antibiotic strategies are appropriate.

Our nomogram provides a rational approach to perioperative antibiotic dosing that may result in a substantial reduction in postoperative infection in populations of children-especially small children - undergoing cardiac surgery. Beyond cardiac surgery, this nomogram may also be translated to other surgeries such as trauma and orthopedic surgeries involving massive blood loss and/or the administration of large volumes of fluids.

\section{References}

1. Barker GM, O’Brien SM, Welke KF, Jacobs ML, Jacobs JP, Benjamin DK, et al Major infection after pediatric cardiac surgery: a risk estimation model. Ann Thorac Surg. 2010;89:843-50.

2. Martone WJ, Culver DH, Haley RW. Incidence and nature of endemic and epidemic nosocomial infections. In: Hospital infections. 3rd ed. Boston: Little, Brown and Co; 1992:577-96.

3. Rosenthal MB. Nonpayment for performance? Medicare's new reimbursement rule. $N$ Engl J Med. 2007;357:1573-5. 
4. Edwards FH, Engelman RM, Houck PM, Shahian DM, Bridges DR, Society of Thoracic Surgeons. The Society of Thoracic Surgeons Practice Guideline Series: antibiotic prophylaxis in cardiac surgery, Part I: duration. Ann Thorac Surg. 2006;81:397-404.

5. Engelman RM, Shahian DM, Shemin R, Guy TS, Bratzler D, Edwards F, et al. The Society of Thoracic Surgeons Practice Guideline Series: antibiotic prophylaxis in cardiac surgery, Part II: antibiotic choice. Ann Thorac Surg. 2007;83:1569-76.

6. Bratzler DW, Houck PM. Antimicrobial prophylaxis for surgery: an advisory statement from the National Surgical Infection Prevention Project. Am J Surg. 2005;189:395-404.

7. Kato Y, Shime N, Hashimoto S, Nomura M, Okayama Y, Yamgishi M, et al. Effects of controlled perioperative antimicrobial prophylaxis on infectious outcomes in pediatric cardiac surgery. Crit Care Med. 2007;35:1763-8.

8. Burke JF. The effective period of preventive antibiotic action in experimental incisions and dermal lesions. Surgery. 1961;50:161-8.

9. Raikhelkar JK, Reich DL, Schure R, Varghese R, Bodian C, Scurlock C. The efficacy of post-cardiopulmonary bypass dosing of vancomycin in cardiac surgery. Semin Cardiothorac Vasc Anesth. 2010;14:301-4.

10. Caffarelli AD, Holden JP, Baron EJ, Lemmens HJM, D'Souza H, Yau V, et al. Plasma cefazolin levels during cardiovascular surgery: effects of cardiopulmonary bypass and profound hypothermic circulatory arrest. J Thorac Cardiovasc Surg. 2006;131:1338-43.

11. Nascimento JW, Carmona MJ, Strabelli TM, Auler JOC, Santos SRCJ. Systemic availability of prophylactic cefuroxime in patients submitted to coronary artery bypass grafting with cardiopulmonary bypass. J Hosp Infect. 2005;59:299-303.

12. Knoderer CA, Saft SA, Walker SG, Rodefeld MD, Turrentine MW, Brown JW, et al. Cefuroxime pharmacokinetics in pediatric cardiovascular surgery patients undergoing cardiopulmonary bypass. J Cardiothorac Vasc Anesth. 2011;25:425-30.

13. Olguin HJ, Asseff IL, Vieyra AC, Perez AG, Saldana NG, Quesada AC, et al. Effect of severity disease on the pharmacokinetics of cefuroxime in children with multiple organ system failure. Biol Pharm Bull. 2008;31:316-20.

14. Nascimento JW, Carmona MJ, Strabelli TM, Auler JO Jr, Santos SR. Perioperative cefuroxime pharmacokinetics in cardiac surgery. Clinics (Sao Paulo). 2007; 62:257-60.
15. Ferreira F, Santos S, Nascimento J, Strabelli T, Carmona M. Influence of cardiopulmonary bypass on cefuroxime plasma concentration and pharmacokinetics in patients undergoing coronary surgery. Eur J Cardiothorac Surg. 2012; 42:300-5.

16. del Rio Mde L, Chrane DF, Shelton S, McCracken GH Jr, Nelson JD. Pharmacokinetics of cefuroxime in infants and children with bacterial meningitis. Antimicrob Agents Chemother. 1982;22:990-4.

17. Powell DA, James NC, Ossi MJ, Nahata MC, Donn KH. Pharmacokinetics of cefuroxime axetil suspension in infants and children. Antimicrob Agents Chemother. 1991;35:2042-5.

18. Nielsen EI, Cars O, Friberg LE. Pharmacokinetic/pharmacodynamic (PK/PD) indices of antibiotics predicted by a semimechanistic PKPD model: a step toward model-based dose optimization. Antimicrob Agents Chemother. 2011;55: 4619-30.

19. Nahata MC, Durrell DE, Ginn-Pease ME, King DR. Pharmacokinetics and tissue concentrations of cefazolin in pediatric patients undergoing gastrointestinal surgery. Eur J Drug Metab Pharmacokinet. 1991;16:49-52.

20. Erez E, Katz M, Sharoni E, Katz Y, Leviav A, Vidne BA, et al. Pectoralis major muscle flap for deep sternal wound infection in neonates. Ann Thorac Surg. 2000; 69:572-7.

21. Viberg A, Lannergard A, Larsson A, Cars O, Karlsson MO, Sandstrom M. A population pharmacokinetic model for cefuroxime using cystatin $\mathrm{C}$ as a marker of renal function. Br J Clin Pharmacol. 2006;62:297-303.

22. Mand'ak J, Pojar M, Malakova J, Lonsky V, Palicka V, Zivny P. Tissue and plasma concentrations of cephuroxime during cardiac surgery in cardiopulmonary bypass - a microdialysis study. Perfusion. 2007;22:129-36.

23. Kosaka T, Hosokawa K, Shime N, Taniguchi F, Kokufu T, Hashimoto S, et al. Effects of renal function on the pharmacokinetics and pharmacodynamics of prophylactic cefazoline in cardiothoracic surgery. Eur J Clin Microbiol Infect Dis. 2012;31:193-9.

24. Pojar M, Mandak J, Malakova J, Jokesova I. Tissue and plasma concentrations of antibiotic during cardiac surgery with cardiopulmonary bypass-microdialysis study. Biomed Pap Med Fac Univ Palacky Olomouc Czech Repub. 2008;152: $139-45$. 